\title{
An Assessment of Record Management System in Establishment Division of Two Universities in Nigeria
}

\author{
Philip Usman Akor *, Julie Udensi ** \\ Department of Library and Information Technology, Federal University of Technology, Minna, Nigeria \\ *,**E-mail address: puakor@gmail.com , julieudensi@yahoo.com
}

\begin{abstract}
The major purpose of this study was to assess record management of the Federal University of Technology, Minna Nigeria and Ibrahim Badamasi Babangida University Lapai, Nigeria. In carrying out this study, four (4) research questions were posed. The study sample population comprised of 88 staff (46 staff from the establishment division of the Federal University of Technology, Minna and 42 staff from the establishment division of the Ibrahim Badamasi Babangida University, Lapai. The instrument used for data collection was questionnaire. The research questions were answered using frequency and percentages. The major findings of the study revealed: ineffectiveness in record management practices, incompetent personnel, inadequate infrastructural facilities, constant power failure. Based on these findings, the following recommendations were made. Effort should be made for provision of standby generator as an alternative to power supply, training of staff to handle the universities' record, provision of adequate fund and enough infrastructural facilities.
\end{abstract}

Keywords: Assessment; Record Management; Establishment Division; Information; Filing

\section{INTRODUCTION}

"Record" means any document or other source of information compiled, recorded or stored in written form or on film, or by electronic process, or in any other manner or by any other means. "State record" means any record made and kept, or received and kept, by any person in the course of the exercise of official functions in a public office, or for any purpose of a public office, or for the use of a public office, whether before or after the commencement of this section. University records are one of its major assets that have value beyond the immediate environment. This means all records which go beyond the boundaries of the office routine, which need to be seen by another or others apart from the creator of the record, and which inform on or contribute to a discussion, debate, enquiry, procedure, or progress of an event. Records represent the tangible product of the work of staff. To recreate them in the event of a total loss would cost millions of naira. The loss of University's records, or even a part of them, could destroy the evidence of students' achievements, staff entitlements and jeopardize the University's rights and interests. International Standard ISO 15489-1:2001 defines records as 'information created, received; and maintained as evidence and information by an organization or person, in pursuance of legal obligations or in the transaction of business.' The ISO 15489: 2001 then goes on to define records management as 'the field of management 
responsible for the efficient and systematic control of the creation, receipt, maintenance, use and disposition of records, including the processes for capturing and maintaining evidence of and information about business activities and transactions in the form of records'. It states that records management includes activities such as:

1. Setting policies and standards;

2. Assigning responsibilities and authorities;

3. Establishing and promulgating procedures and guidelines;

4. Providing a range of services relating to the management and use of records;

5. Designing, implementing and administering specialized systems for managing records; and

6. Integrating records management into business systems and processes.

Decision making in the university system is an administrative function and invariably requires information in the form of records. Administration is ordinarily discussed as the art of "getting things done." Emphasis is placed upon processes and methods for insuring incisive action. Principles are set forth for securing concerted action from groups of people. Decisions are made at different levels in the university. However, it is fairly obvious that the lower one goes down the organization the lower the level of decision that must be made and in reverse, the higher one goes the higher the level of decision; irrespective of the level, however, information will be required one way or another. In all spheres of activity decisions are being made about the allocation of budgetary resources, the prioritization of programmes, the granting of social benefits, the commissioning of new projects, the closure of unproductive ventures, the information to release to the public or the level of classification that certain information requires. Records and archives provide the information that is required by those who make the decisions. The question only is whether these records are available to these decision makers and whether the decision makers are aware of their existence and thus make use of them when making decisions.

Record keeping occupies a strategic position in the efficient and effective management of the university system. In fact, it is central in the administration of institutions of learning because it documents the planning and implementation of appropriate course of services allowing proper monitoring of work. In the conventional paper based organizations such as the universities, paper continues to be viewed as the material for records in administrative documentations (Igwoku 2008). Generally, record keeping must be guided by some level of confidentiality, proper maintenance, security, preservation of the content and context, etc (Iwhiwhu 2007). Writing in support of the above finding, Ibiam (2004) noted that many years of neglect had done great damage to the education sector and record keeping is not an exemption. In his view, Iguodala (1998) believes that personnel (secretaries and filling clerks) who maintain the registry systems with filing cabinets containing the paper evidence of university business are inadequate and in fact ignorant of their responsibilities.

Educational institutions are general centers for data generation and by extension records keeping. It has become a recurrent issue for records to be irretrievable when required specially in Nigerian tertiary institutions (Fabunmi, 2004). The reasons for this cannot be well understood. The complexity of this problem is better appreciated by those who bear the brunt especially university teachers, students, parents and administrators who require students records to facilitate accurate, timely decisions.

The foregoing seems to point to the need for a sound record management system (RMS), in our higher institution. (Okwilagwe and Njoku 2002) agrees that the development of RMS in Africa is due to certain inhibitive factors such as; lack of infrastructure, untrained personnel to handle equipment and absence of MIS based policy. The above is in line with Isah (1999) who 
identified personnel, lack of basic infrastructure as requirements for an efficiently based MIS at the tertiary education level.

Furthermore, (Nwankwo, 2000) identified level of training of personnel in records keeping offices as inhibitive to proper records management. He who identified poor infrastructure undefined policy gap and a poor awareness base as reasons for a poor MIS base in tertiary institutions. There must be a conscious effort to plan records retrieval to eradicate the problem of document retrieval. (Longe, 2001) describes a plan as a series of actions that have future consequences. Plans have time frames (Akangbou, 2003). There are various types of plans such as; strategic plan, Development plan, sectorial plan, long term and short term planning. The same applies to the fact that we have educational planning. Majority of the activities carried out in universities are planned from the academic planning units making use of policies developed corporately. (Nwankwo, 1999), (Lundu and Mbewe 1998) agree that a good record retrieval system must be a component part of an effective (MIS). Nwankwo identified two types of management information systems. These are the manual MIS which has to do with records keeping through the use of files, indexing and classifications and filing by Clerks and office staff, while the computerized MIS deals with records input, processing and retrieval through electronic machines.

Records management is the weakest link in Federal University of Technology, Minna and Ibrahim Badamasi Babangida University, Lapai. This weakness will not deter organizations from adopting the product. University's strengths in other areas, particularly the flexibility it provides teams in setting up their own collaborative environment, together with the strength of administrative position, has ensured proper management of student records. University Managements have come up with an innovative records management model of their own for administering students' record. The following are the Roles of record management in Federal University of Technology, Minna and Ibrahim Badamasi Babangida University, Lapai Space savings is the most immediately realized benefit of a records management program. By implementing retention schedules and systematically destroying records that have met their retention requirements, the University management was able to significantly reduce the space occupied by records.

Control over creation of new records: A significant percentage of the cost of information is in records creation. Records management, forms management, and reports management can help reduce the proliferation of unnecessary reports, documents, and copies, and at the same time improve the effectiveness of those reports and documents that do need to be created.

\section{STATEMENT OF THE PROBLEM}

Perhaps it would not be an overstatement to say that record keeping problems are common to the different levels of the education sector. It is however becoming clearer that it is more pronounced in the university system because accurate, reliable and trustworthy records that fulfill evidential requirements are being created but not properly managed. This therefore becomes an issue of great concern to government, parents, students, individuals and organizations. In the past, frantic efforts to improve the situation in many universities through the introduction of computers and internet services as well as development of database management system do not seem to have helped the situation much because the record management system is still conventionally paper-based and manual in operation. Many management staff complains of funds and material resources. The reality reveals gross inadequacy of qualified personnel, facilities, students' explosion and space problem. This study 
is therefore a response to the challenge by striving to empirically identify these problems and well defined management options that could improve record keeping processes in universities especially in the study area.

\section{OBJECTIVES OF THE STUDY}

The objectives of the study are to determine:

1. The legislative framework regulating the management of public records at the Federal University of Technology, Minna and Ibrahim Badamasi Babangida University, Lapai.

2. How information is managed in an Electronic Record Management system at the Federal University of Technology, Minna and Ibrahim Badamasi Babangida University, Lapai.

3. The problems associated with record management in F.U.T., Minna and IBBU Lapai.

4. The effectiveness of record management at F.U.T., Minna and IBBU Lapai.

5. The best practices of ensuring records management.

\section{SIGNIFICANCE OF THE STUDY}

The study is based on the premise that file management of records in Nigerian universities is not efficient. It is an inquiry into the state of record-keeping in the F.U.T., Minna and IBBU Lapai university system with a view to proposing strategies that will make for better recordkeeping in the institutions. It is therefore not out of place to expect that the study will be of benefit to the Nigerian government who can be rest assured by the knowledge that not only can management at F.U.T., Minna and IBBU Lapai keep good records but also that the government can get hold of the data whenever required. The university administrations will also benefit as the study will illuminate the stale areas of record-keeping in the universities and also create awareness on how to manage records more effectively with less stress. University staff, students and graduates will not be left out as they will begin to enjoy the blessings of getting required records in their accurate form and within a small space of time.$:$ It is hoped that the study will be an invaluable contribution to the only small amount of work that has been done on the lingering issue of university record management and that it will provoke more researches which will largely draw more attention to this important subject.

\section{SCOPE OF THE STUDY}

The study was limited to faculties and schools located on the Gidan Kwanu campus of F.U.T., Minna and IBBU Lapai campus. All the offices that participated in the study were located on the same campus though the F.U.T., Minna has Bosso campus. The survey of all campuses was deemed unnecessary because the overall picture of how records are managed at the F.U.T., Minna and IBBU Lapai is an aggregate picture of the records management practices and procedures on all campuses of the University. Admittedly, different units are likely to be motivated differently on how to manage their records, but guiding principles are likely to be similar university-wide.Therefore, this research studied practices and procedures of records management in the offices where schools and faculties manage their records on the F.U.T., Minna and IBBU Lapai campus. 


\section{LITERATURE REVIEW}

Records can be described as a collection of related items of data treated as a unit while data are facts or figures from which conclusions can be referred (Folorunsho, 2003). Again, records can be described as logical collection of data. O'brien (1998). Data can also be described as the logical collection of items. UNESCO (1999) such items could be statistics, Alphanumeric quantities. The foregoing show that records are an important collection of facts from which inferences can be drawn.

Educational institutions are general centers for data generation and by extension records keeping (Nwankwo, 2001). University programmes have become extremely complex over the years. It has become a recurrent issue for records to be irretrievable when required specially in Nigerian tertiary institutions (Fabunmi, 2004). The reasons for this cannot be well understood. The complexity of this problem is better appreciated by those who bear the brunt especially university teachers, students, parents and administrators who require students records to facilitate accurate, timely decisions (Nwankwo 2001). Decision making is the backbone of administrative actions and administrators execute plans through actions (Igwe, 2002). The growth in tertiary institutions in Nigeria has been on the increase since the oil boom era (Mbat, 2001). This is buttressed by the fact that more tertiary institutions of private ownership spring up daily by virtue of the liberalization of education in Nigeria (NPE, 1998). With the forgoing, it is convincing that there is a regular data generation in Nigerian Universities. Nwankwo (2001) observed that Nigerian tertiary institutions have an information generation capacity of $76 \%$ and a utilization capacity of $3 \%$. The gap in generation of information and utilization naturally raises queries as to what happens to the generated information. Lundu and Mberve (2004) decried the inability of must educational institutions to put up sound information management policies to guide the generation, processing, storage and retrieval of stored data.

Recently, the Council on Higher Education (2000) pointed out that higher education information systems in South Africa were inadequate. Proper records management could help universities to manage their information, efficiently fulfils their mandate, protect them from litigation, preserve their corporate memory, and foster accountability and good governance. The information contained in university records needs to be managed according to a methodical approach in order to enhance the effectiveness and efficiency of the universities in carrying out their mission. As universities carry out their mission they create various records.

The core business of universities is learning, teaching, research and community development. The University of KwaZulu-Natal, in articulating its mission, states that it is 'committed to academic excellence, innovation in research and critical engagement with society' (University of KwaZulu-Natal 2005). Carrying out these activities produce records, which provide evidence that the University is carrying out its statutory functions. If such records are not properly managed or misplaced, then valuable evidence would be lost forever/Proper management means establishing systematic controls at every stage of the record's life cycle, in accordance with established principles and accepted models of records management.

A personal experience and general observation reveals that access to students records are difficult in virtually all Nigerian Universities. Records which are difficult to access include: students progress transcripts, final year students academic transcripts. Such delayed access to vital records and documents creates lags in candidates' further progress either for postgraduate studies or employment purposes. Nwankwo (2001) explains that the growing complexity of the university systems enhances information generations through distant learning, admission processes to university, matriculation, etc. The volume of information generated is heavy and hence require adequate management. Given the doubtless significant of educational records, 
Asogwa (2004) noted that data which arise from the execution of legitimate functions of schools should be properly managed and secured. Unfortunately, this has not been the case in most institutions as Omenyi (1998) observed. According to Afolabi (2004) and Egwuyenga (2009), records management in Nigeria is plagued by such factors as inadequate skilled and experienced management personnel, lack of sufficient funds and the placement of records management in a low priority pedestal in relation to other things. These problems have eaten deep into records management practice in Nigerian universities. In addition, archaic record-keeping methods and technology plus poor data storage facilities are part of the problems militating against record management.

In this light, the proper management of university records in F.U.T., Minna and IBBU, Lapai becomes very important. Universities might find themselves in an embarrassing position if requested records are not found as a result of poor records systems where, as Taylor (2000) notes, litigation by aggrieved parties cannot be ruled out. Recently, a former University of Durban- Westville student made a court application demanding to see his examination scripts (UKZN rejects marks allegations 2004). Although, the student eventually lost his case at the Pietermaritzburg High Court, the case demonstrates the possibly consequence of not providing information timeously. Organizations that manage their records well reap immediate benefits in terms of being able to utilize all available information resources for competitive advantage.

Kemoni and Wamukoya (2000) state that effective records management systems provide information required for the proper functioning of organizations, including universities. On the other hand, poor records management can be risky to organizations. Djorka and Conneen (1998) summarize the consequences of poor records management as follows: "an institution where paperwork is poorly managed, the flow of records through the life cycle is retarded, chaotic, or non-existent. Records and the information they contain are difficult to retrieve, and costly duplication of paperwork is a frequent occurrence. The net effect of poor management is a decrease in the efficiency of the institution and an inflation of its operating costs".

\section{RESEARCH METHODS}

Survey research method was used to carry out this research because of its large population. Nworgu (2006) attested that a survey research is one in which a group of people or items is studied by collecting and analyzing data from only a few people or items considered to be representative of the entire group. Purposive sampling technique was used in selecting 46 staff out of 120 staff of the establishment division of Federal University of Technology, Minna and 42 staff out of 110 staff of the establishment division of Ibrahim Badamasi Babangida University, Lapai making the total population of the study to be 88 . The instrument used for sollecting data for this study was questionnaire.

The instrument before use was face-validated by presenting it to three senior colleagues in the field of Library and Information Science. These experts were requested to examine the clarity of expression used as well as the appropriateness of language. The researcher administered and collected the questionnaire from the respondents. Thus there was a $100 \%$ rate of returns of the questionnaires distributed. The data for the study was presented in tables and analysed using simple percentage method of statistics. 


\section{PRESENTATION AND ANALYSIS OF DATA}

Out of the 88 copies of the questionnaires that were administered to the staff of the establishment division of the two universities $88(100 \%)$ were retrieved. The data from the retrieved questionnaires are hereby presented using simple statistics like frequencies and percentages.

Table 1. Respondents by Gender.

\begin{tabular}{|c|c|c|c|c|}
\hline Sex & $\begin{array}{c}\text { Frequency } \\
\text { (FUT, Minna) }\end{array}$ & $\begin{array}{c}\text { Frequency } \\
\text { (IBBU Lapai) }\end{array}$ & Total & Percentage (\%) \\
\hline Male & 31 & 28 & 59 & 67.05 \\
\hline Female & 15 & 14 & 29 & 32.95 \\
\hline Total & 46 & 42 & 88 & 100 \\
\hline
\end{tabular}

Table 1 showed the gender of the respondents. 59 (67.05\%) of the respondents were male while, $29(32.95 \%)$ of the respondents were female from both institutions.

Table 2. Do you use or refer to the File Plan when Creating Correspondence.

\begin{tabular}{|c|c|c|c|c|}
\hline Sex & $\begin{array}{c}\text { Frequency } \\
\text { (FUT, Minna) }\end{array}$ & $\begin{array}{c}\text { Frequency } \\
\text { (IBBU Lapai) }\end{array}$ & Total & Percentage (\%) \\
\hline Yes & 27 & 31 & 58 & 65.91 \\
\hline No & 19 & 11 & 30 & 34.09 \\
\hline Total & 46 & 42 & 88 & 100 \\
\hline
\end{tabular}

A file plan provides means of knowing what records exist and where they are kept. Although most respondents $58(65.91 \%)$ indicated that they refer to the File Plan when creating their correspondence while 30 (34.09\%) of the respondents were not make use of the File Plan. The results reflected in table 2 simply implies that $34.09 \%$ of record management officials in both. Institutions under study do not include file reference numbers when creating documents and that may lead to dislocation and illegal destruction of documents. 
Table 3. Where should records be kept for easy access?

\begin{tabular}{|c|c|c|c|c|}
\hline Option & $\begin{array}{c}\text { Frequency } \\
\text { (FUT Minna) }\end{array}$ & $\begin{array}{c}\text { Frequency } \\
\text { (IBBU Minna) }\end{array}$ & Total & Percentage \\
\hline In individual offices & 11 & 8 & 19 & 21.59 \\
\hline Centralized at records offices & 35 & 34 & 69 & 78.41 \\
\hline Total & 46 & 42 & 88 & 100 \\
\hline
\end{tabular}

In table 3 question was made to know where the records should be kept in the institution. $19(21.59 \%)$ of the respondents were of the opinion that records should be kept in the individual offices while, the majority of the respondents representing $69(78.41 \%)$ felt that records should be centralized at the records office.

Table 4. Do you regard records as one of the important resources that would enable universities to carry out its mandate effectively? If yes why, if no why?

\begin{tabular}{|c|c|c|c|c|}
\hline Option & $\begin{array}{c}\text { Frequency } \\
\text { (FUT Minna) }\end{array}$ & $\begin{array}{c}\text { Frequency } \\
\text { (IBBU Lapai) }\end{array}$ & Total & Percentage \\
\hline Yes & 46 & 42 & 88 & 100 \\
\hline No & - & - & - & - \\
\hline Total & 46 & 42 & 88 & 100 \\
\hline
\end{tabular}

All the respondents from both institutions under study regard records as one of the important resources in enabling university to carry out its mandate effectively, due to the following:

- Records ensure orderly and efficient flow of information that enables university officials to perform their functions successfully and efficiently;

- Institutional memory assists in improving the way things are done;

- Records form the basis for formulating policies, future plans and making informed decisions;

- Consultation, in which availability of records is important, is crucial in good service delivery;

- Without records, an organization cannot function;

- Having accurate and up-to-date information ensures a better service to the communities. 
Table 5. Adequate Funding can Enhance Effective record Management.

\begin{tabular}{|c|c|c|c|c|}
\hline Option & $\begin{array}{c}\text { Frequency } \\
\text { (FUTMinna) }\end{array}$ & $\begin{array}{c}\text { Frequency } \\
\text { (IBBU Lapai) }\end{array}$ & Total & Percentage \\
\hline SA & 21 & 24 & 45 & 51.14 \\
\hline A & 18 & 16 & 34 & 38.64 \\
\hline D & 6 & 2 & 8 & 9.09 \\
\hline SD & 1 & - & 1 & 1.14 \\
\hline Total & 46 & 42 & 88 & 100 \\
\hline
\end{tabular}

Table 5 clearly show that $45(51.14 \%)$ of the respondents strongly agree that adequate funding can enhance effective record management, 34 (38:64\%) of the respondents agree to the statement, $8(9.09 \%)$ of the respondents disagree while, $1(1.14 \%)$ of the respondent from FUT, Minna strongly disagree to the notion.

\section{DISCUSSION}

A brief summary of the findings derivedJr0m the results presented in the preceding discussion is outlined below. It is necessary to summarise the findings to be able to recommend best practices in ensuring sound records management, which follows in the next chapter.

The research questions that were posed in Chapter One were taken into consideration, and it will be established whether the survey results attempted to address them. It is worth noting that the survey results presented more weaknesses in ADM',s records management practices than strengths. The summary of the findings is sub-divided into topics, as follows:

\section{Usage of the File Plan}

Proper usage of and understanding a file plan is fundamental to ensuring an effective records management system. The file plan guides officials on the allocation of file reference numbers for easy filing and retrieval. Only $65.91 \%$ of respondents indicated that they make use of the file plan.

The fact that the remaining $34.09 \%$ of respondents do not use a file plan should be a wake-up call to university record management since it can lead to disastrous situations in the future.

\section{Storage of records}

University Records Management Policy stipulates clearly that the records office is the official location where information resources are kept. Nevertheless, only $17.05 \%$ of respondents confirmed that they always forward correspondence to the records office, the rest $(82.95 \%)$ occasionally or never forward the correspondence to the records office. Interestingly, $69(78.41 \%)$ of the respondents agree that records should be kept at the records office as against the $19(21.59 \%)$ who are of the view that they should be kept in individual offices. 


\section{The impact of records management in decision making}

All of the respondents who answered this question confirmed the vital impact of effective records management in decision-making. Effective records management facilitate timely and efficient decision-making, promote public participation, inform future decisions, produce evidence in litigation cases, increases accountability of decision-makers and fast-track service delivery.

\section{Contribution of records management towards effective administration at university}

All respondents $88(100 \%)$ agree that records management contributes towards effective administration at university, and consequently towards effective and efficient delivery of services to the students, lecturers and the community. Respondents stated that records management ensures the orderly and efficient flow of information which enables university officials to perform their functions successfully and efficiently.

Records management also forms the basis for formulating policies, future plans and informed decision making. Without records, an organization cannot operate. From this analysis the relationship is evident between the two variables, namely, records management and effective administration of a service oriented organization, and the hypothesis has been tested to be true.

\section{Current records management practices at your university}

The opinion on of a large proportion of the respondents $56(63.64 \%)$ is that records management at university is not receiving the attention it deserves. Some of the reasons cited for this view are non-usage of the File Plan, lack of training of both records office staff and users (staff), unskilled and demotivated records office staff and lack of support from top management.

\section{SUMMARY OF FINDINGS}

The main objective of this study was to assess significant of record management in the establishment of Federal University of Technology, Minna and Ibrahim Badamasi Babangida University, Lapai. Records management is a function that is generally underestimated and is always aligned with low level officials. Conversely, records management is a process of maintaining and enhancing information, and information is a fundamental resource to both private and public sectors alike. Records are essential to the administration of local government as they contain the information that keeps government programmes functioning.

The main objective of this study was to investigate the role played by records management in the university administration.

The primary question that was explored was whether the management of records receives the attention it deserves at both universities under study. By conducting this study, the aim of the researcher was to create awareness and sensitise university administrators, particularly top officials, that ineffective management of records indirectly affects the performance of the university and may have adverse effects on the delivery of services, by either delaying or hampering the service delivery process. 


\section{CONCLUSION}

The main aim of the research was to conduct an investigation on the role of Records management, with specific reference to Federal University of Technology Minna and IBBU Lapai. The research was based on the hypothesis that effective records management plays a significant role in the effective administration of a service oriented organisation and the primary research question was whether the management of records receives the attention it deserves at the selected case study.

The study has revealed that records management does play a significant role in various aspects including, inter alia, risk management process, strategic planning process, bettering performance and improving service delivery, promoting good governance, supporting democratic accountability, fulfilling legal requirements, combating corruption, promoting and protecting human rights and ensuring sound financial management. Nonetheless, based on the empirical survey findings, it can be concluded that records management is not receiving the attention it deserves at IBB Lapai and Federal University of Technology Minna. In its endeavours to improve its records management practices, it is proposed that University management of the selected case study consider the findings and recommendations of this study.

\section{Recommendations}

It is recommended that the Records Manager be provided with adequate training to ensure that this official is able to undertake the full responsibilities of the post. The position of the Records Manager is crucial as this official is entrusted with the responsibility of overseeing the welfare of the organisation's records. Also, to ensure improvement of Institution's records management practices, the Records Manager should be dedicated only to the records management function. University Management should appoint separate Records Managers for the Budget and Treasury Office, Human Resources, they should be charged with the responsibility of ensuring sound records management within their respective divisions. Such Records Managers should remain accountable to the Records Manager of the whole organisation.

Furthermore University manage should speed up the process of developing a Records Control Schedule so as to be able to control and manage all University records and prevent unauthorised removal and destruction of records. University Management should ensure that the Records Manager participates in the risk management programme so as to ensure that all records management related risks are brought to the attention of management and are included in strategic and budget plans. Furthermore, it is critical that a Records Management Disaster Prevention and Recovery Plan be developed to prevent the disruption of Institutional critical operations should a disaster occur. Since this is a critical factor, it is advised that it be incorporated into the organisation-wide strategic plans.

The Record Manager will require the cooperation of the Information Technology Manager with regard to the electronic records. 


\section{References}

[1] Afolabi M. (2004). Educational Training Archivists and Record Managers in Africa. Annual Conference Procedure of the Society of Nigerian Archivists, Lagos: SNA, pp. 61-67.

[2] Akangbou S. D. (2003). The Economics of Educational planning in Nigeria, Vikas publishing House, PVT Ltd Anseri Road, New Delhi, India pp. 13.

[3] Fabunmi M. (2004). Perspective in Educational Planning.u0dun Prints and pack; Agbowo, Ibadan Nigeria.

[4] Ibiam N. (2004). Education Banking: Facts Figures and Benefits: A Paper Presented at a Seminar Organized by the Rivers State Ministry of Education for Private Schools Operators. April, 27-28, 2004.

[5] Iguodala W. A. (1998). Records in Educational Management in Educational Management for Sub-Saharan African. Mon Nwadiani Dimensions of Education Series No 2. Nigerian Society for Educational Planning (NSEP) Monose Amalgamates.

[6] Igwoku I. F. (2008). An Analysis of Record Management Strategies in Western Nigeria. M. Ed. Dissertation, Unpublished. Abraka: Delta-State University.

[7] Isah E. A (2007). Institutional Records Management Analysis of Students Academic Records: A case study of the University of Ibadan. Unpublished M. Ed thesis of the Department of Educational Management, University of Ibadan

[8] Iwhiwhu E. B., The Journal of Electronic Library 23(3) (2005) 345-355.

[9] Kemoni H., Wamukoya J. (2000). Preparing for the management of electronic records at Moi Kenned Jay \& Cherryl Schauder (1998). Records Management: A Guide to Corporate Record Keeping. Melbourne: Longman.

[10] Longe R. S. (2001). Introduction of Educational Planning. Seminar paper of the Educational planning Unit. Department of Educational management, University of Ibadan.

[11] Lundu M. C., Mbewe G. (2004). Factors retraining the formulation and Implementation of National Information Policy (NIP) Process.

[12] Nwankwo J. I. (2001). Fundamental of Management information systems. Spectrum books Ltd., Ibadan.

[13] Nworgu B. G. (2006). Educational Research Basic Issues and Methodology. Enugu University.

[14] O’brien I. A. (1998). Foundation to Information systems, Irvin Megraw Hill Companies U.S.A.

[15] Okwilagwe O. A., Njoku I. F. (2002) Availability and Accessibility of ICTS to Nigerian publishers for book marketing business. African Journal of Educational Management Vol. 10. No 2: Journal of Department of Educational Management University of Ibadan. 
[16] Omeyi A. S. (2002). Effective Record Management, a Tool for Effective Counselling in the School System. Journal of Counselling and Communication, (Counselling Association of Nigeria, Anambra State Chapter in Conjunction with Guidance and Counselling Units, Nnamdi Azikiwe University, Awka).

[17] Penn I. A., Pennix G., Coulson I. (1994). 'Records management handbook' 2nd ed. Gower p.7 An assessment of the current evidence base demonstrating the benefits of investing in the improvement of records management 21 of 27.

[18] Popoola S. O. (2000). A cost model approach to records management system in the Oyo State Civil Service, Nigeria. A Ph. D Thesis, University of lbadan, Ibadan.

[19] Popoola S. O., Oluwole D. A., Career commitment among records management personnel in a state civil service in Nigeria. Records Management Journal 17(2) (2007)

[20] South Africa. Records Management Policy Manual. [Online] Available from: http://www.national.archives.gov.za [Accessed: 13 June 2012].

[21] Thomassen T. (2002). A first introduction to archival science. Kluwer Academic Publishers: Amsterdam.

[22] Ugwunze V. I. (1999). An examination of records management in the University of Lagos registry. Archives and Information Science 2(1): 34-46. University, Kenya: a case study. African Journal of Library, Archives and Information Science. Oct; 10(2): 125-38.

[23] Van der Waldt G., Van Niekerk Doyle M., Knipe A., Du Toit, D. (2002). Managing for results in government. Sandown: Heinemann.

[24] Van der Waldt G., Venter S., Phutiagae K., Khalo T., Van Niekerk D., Nealer E. (2007). Municipal Management: Serving the People. Cape Town: ABC Press. 